\title{
Profil Kimia dan Toksisitas Jamu Berpotensi Antidiabetes yang Diformulasi dengan Metode Statistika dan Machine Learning
}
Penulis
Norma Nur Azizah ${ }^{1,4^{*}}$, Rudi Heryanto ${ }^{1,2}$, Wisnu Ananta Kusuma ${ }^{2,3}$
Afiliasi
${ }^{1}$ Departemen Kimia, Fakultas Matematika dan Ilmu Pengetahuan Alam, Institut Pertanian Bogor
${ }^{2}$ Pusat Studi Biofarmaka Tropika, Institut Pertanian Bogor.
${ }^{3}$ Departemen Ilmu Komputer, Fakultas Matematika dan Ilmu Pengetahuan Alam, Institut Pertanian Bogor
${ }^{4}$ Klaster Drug Development Research Center (DDRC), Indonesian Medical Education and Research Institute (IMERI) , Fakultas Kedokteran Universitas Indonesia.

\section{Kata Kunci \\ $\rightarrow$ Antidiabetes \\ Formulasi jamu \\ $\Rightarrow \mathrm{LC}_{50}$ \\ Optimasi \\ $\rightarrow$ Profil kimia}

Diterima 14 November 2017 Direvisi 26 Februari 2018 Disetujui 15 Maret 2018

*Penulis Korresponding Norma Nur Azizah Jl. Salemba Raya No.6 Jakarta (IMERI-FKUI)

normanurazizah.92@gmail.co $\mathrm{m}$

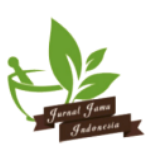

\section{ABSTRAK}

Pengetahuan tentang cara meracik ramuan jamu dan membuat komposisinya belum diketahui secara jelas. Saat ini upaya memformalkan struktur formula jamu telah dilakukan. Penelitian ini bertujuan memformulasi jamu baru yang memiliki efek hipoglikemik, menentukan toksisitas, dan profil kimia jamu, serta membuat formula jamu optimum. Formulasi jamu menggunakan 3 metode, yaitu partial least squaredeterminant analysis (PLS-DA), koefisien PLS multiways, dan support vector machine (SVM) menghasilkan formula dari tanaman campuran, yaitu brotowali, secang, jambu biji, dan sambiloto. Persen komposisi tanaman campuran dianalisis menggunakan perancangan percobaan, diperoleh 9 komposisi formula jamu. Profil kimia setiap formula jamu ditentukan menggunakan metode kromatografi lapis tipis. Dari profil kimia setiap formula diperoleh rerata jumlah pita sebanyak 5 hingga 6 pita. Dari toksisitas formula diperoleh nilai rerata $\mathrm{LC}_{50}$ berkisar $426-639 \mathrm{ppm}$. Formula optimum diperoleh menggunakan piranti lunak Design Expert 7.0 dengan LC $_{50} 456$ ppm. Nilai $\mathrm{LC}_{50}$ lebih kecil dari 1000 ppm, yang berarti formula jamu optimum berpotensi sebagai jamu antidiabetes.

\section{PENDAHULUAN}

Jamu dipercaya masyarakat Indonesia untuk mencegah bahkan mengobati suatu penyakit dan telah banyak digunakan selama bertahun-tahun yang lalu. Walaupun telah banyak digunakan, pengetahuan cara meracik ramuan jamu dan membuat komposisinya belum diketahui secara jelas. Saat ini upaya memformalkan struktur formula jamu telah dilakukan. Pusat studi biofarmaka (PSB) pada tahun 2011 telah melakukan penelitian tentang keteraturan pola pada sistem jamu melalui pendekatan pangkalan data statistika jamu. Penelitian tersebut menunjukkan bahwa suatu jamu yang memiliki khasiat tertentu mempunyai aktivitas farmakologis tertentu. Studi ini menunjukkan hasil bahwa terdapat keteraturan dari beberapa aktivitas farmakologis yang dimiliki oleh masing-masing khasiat jamu. Pola keteraturan tersebut memberikan struktur formula jamu yang terdiri atas tiga jenis aktivitas pendukung, yaitu aktivitas 
farmakologis analgesik, antimikrob, dan antiinflamasi serta satu aktivitas utama. Tanaman utama memiliki efek langsung pada penyakit sehingga menjadi tanaman yang langsung dihubungkan dengan khasiat tertentu (Afendi et al. 2010).

Afendi et al. (2012) menggunakan metode partial least squares- discriminant analysis (PLS-DA) untuk mengembangkan sebuah model klasifikasi formula jamu. Penelitian tersebut difokuskan pada pengamatan 3138 sampel jamu yang diklasifikasikan ke dalam 9 jenis khasiat. Khasiat yang dapat diprediksi oleh metode ini adalah urinary related problems (URI), disorder of apetite (DOA), disorder of mood and behavior (DMB), gastrointestinal disorders (GST), female reproductive organ problems (FML), muskuloskeletal and connective tissue disorders (MSC), pain and inflammation (PIN), respiratory disease (RSP), dan wounds and skin infections (WND). Sampel jamu yang digunakan mengandung 1 sampai 16 tanaman yang diambil dari 465 tanaman obat. Upaya memformalkan formulasi jamu dapat dilakukan dengan teknik machine learning salah satunya dengan menggunakan suport vector machine (SVM). Metode ini pernah dilakukan oleh Fitriawan (2013), dalam penelitiannya berhasil mengimplementasikan sistem klasifikasi jamu sederhana dengan metode SVM yang dapat digunakan untuk memprediksi kandidat-kandidat formula jamu baru. Beberapa penelitian terakhir terkait penggunaan data dan aplikasi teknik statistika tersebut telah dilakukan. Andriana (2014) melakukan formulasi jamu baru berkhasiat antikolesterol menggunakan pendekatan statistika PLS, koefisien multiways, dan SVM. Nurishmaya (2014), dalam penelitiannya memformulasikan jamu baru berkhasiat antidiabetes menggunakan pendekatan PLS, koefisien multiways, dan SVM pada penelitiannya tanaman yang dipilih berdasarkan pendekatan khasiat diformulasikan secara acak yang memiliki aktivitas farmakologi tersebut dan mempunyai khasiat target dipilih dan diujikan secara laboratorium. Namun, pengujian terhadap ikan zebra sebagai hewan uji belum menunjukkan hasil yang baik. Maka dari itu perlu dilakukan penelitian dan pengembangan lebih lanjut dalam pemilihan tanaman untuk formulasi jamu antidiabetes.

Pemilihan tanaman untuk memformulasikan jamu menjadi salah satu faktor keberhasilan dalam menentukan khasiat jamu, sehingga diperlukan kelompok tanaman yang telah diuji melalui penelitian yang mempunyai khasiat tertentu. Wijaya et al. (2014) melakukan prediksi antara hubungan tanaman dan jenis penyakit menggunakan formula jamu pada KNApSAcK Database. Penelitian ini menunjukkan adanya hubungan antara tanaman dan penyakit yang dapat diobatinya, hasilnya terdapat 11 jenis khasiat yang dapat dikorelasikan dengan tanaman yang berkhasiat tertentu. Dalam penelitiannya 11 jenis khasiat dikorelasikan dengan 9 jenis khasiat yang telah dikelompokan Afendi et al.(2012). Dari database tersebut dipilih 4 jenis tanaman yang berkhasiat sebagai antidiabetes dan diprediksi menggunakan PLS sampai mendapatkan respon khasiat tertinggi (Afendi et al. 2012). Berdasarkan penelitian Ristyawan (2014) berhasil mengelompokkan 26 jenis tanaman untuk khasiat GST dengan metode voting feature interval 5.

Penelitian ini bertujuan memformulasikan jamu baru yang memiliki efek hipoglikemik dengan pemilihan tanaman yang difokuskan pada penelitian Wijaya et al. (2014), Ristyawan (2014) dan Afendi et al. (2012). Tujuan ini dicapai melalui: (i) Formulasi tanaman terpilih melalui metode statistika (PLS, koefisien PLS multiway) dan machine learning (SVM); (ii) Pembuatan komposisi jamu menggunakan piranti lunak Design Expert 7.0 ${ }^{\circledR}$; (iii) Optimasi formula jamu berbasis toksisitas dan; (iv) Pembuatan profil kimia formula jamu menggunakan metode kromatografi lapis tipis yang didukung oleh piranti lunak ImageJ berbasis kurva densitogram dan luas area kurva.

\section{METODE}

Penelitian dilakukan dengan beberapa tahap, yaitu: Pemilihan kandidat jamu baru menggunakan metode partial least square-discriminant analysis (PLS-DA), koefisien PLS Multiways dan metode support vector machine (SVM); formulasi dan persiapan jamu terpilih; uji toksisitas menggunakan metode brine shrimp lethality test (BSLT), analisis sidik jari menggunakan metode kromatografi lapis tipis formula jamu terpilih dan optimasi komposisi formula jamu.

\section{Pemilihan Kandidat Jamu Baru}

Data tanaman yang digunakan merupakan hasil penelitian Wijaya et al. (2014), Ristyawan (2014), dan Afendi et al. (2012) yang dikelompokkan kedalam 4 aktivitas farmakologis, yaitu tanaman utama, analgesik, antibakteri, dan antiinflamasi. Pemilihan kandidat jamu baru dilakukan dengan menggunakan model partial least squares-discriminant analisys (PLS-DA), koefisien PLS multiways, dan metode SVM. Model PLS-DA dan

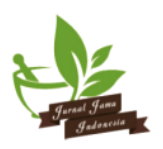


koefisien PLS multiways diperoleh dari hasil penelitian Afendi (2010) sedangkan model SVM diperoleh dari hasil penelitian Fitriawan (2013).

Sebanyak 150 formula jamu yang terdiri atas 4 tanaman dimasukkan ke dalam piranti lunak $\mathrm{R}$ i386 2.15.2 untuk metode PLS-DA dengan jamu sebagai prediktor dan khasiat sebagai respon. Untuk metode koefisien PLS dilakukan dengan cara menjumlahkan koefisien tiap tanaman yang mempunyai aktivitas farmakologis berbeda. Untuk metode SVM, sebanyak 150 formula jamu baru dibuat berupa hubungan antara jamu, komponen penyusun jamu, dan khasiat menggunakan sistem biner. Formula jamu tersebut diolah menggunakan model SVM yang telah tersedia. Formula jamu terpilih adalah formula jamu yang memiliki khasiat GST. Contoh representasi hubungan jamu, komposisi jamu dan khasiat terlampir pada Lampiran 3. Kriteria pemilihan jamu baru, yaitu memiliki khasiat GST berdasarkan prediksi menggunakan model PLS, koefisien PLS multiways, dan metode Support Vector Machine (SVM), serta ketersediaan di alam.

\section{Formulasi dan Pembuatan Jamu}

Keempat tanaman terpilih diformulasikan dengan piranti lunak Design Expert $7.0^{\circledR}$. Pendekatan yang digunakan adalah mixture dengan desain simplex lattice dengan total bobot $10 \mathrm{~g}$ dan lethal concentration (LC50) sebagai respon. Selanjutnya, dilakukan pengoleksian tanaman yang diperoleh dari kebun percobaan Pusat Studi Biofarmaka (PSB) Bogor. Tanaman dibersihkan dengan air mengalir hingga bersih lalu dikeringkan dan dihaluskan dengan ukuran serbuk 40 mesh. Simplisia tanaman ditentukan kadar airnya menggunakan metode AOAC (2007).

Jamu dibuat dengan menimbang serbuk tanaman sesuai komposisi hasil desain. Bobot total tiap komposisi jamu adalah $10 \mathrm{~g}$. Setelah itu, komponen jamu dimasukan kedalam erlenmeyer $500 \mathrm{~mL}$ lalu ditambahkan $200 \mathrm{~mL}$ akuabides, lalu dipanaskan hingga mendidih dan volumenya menyusut menjadi $100 \mathrm{~mL}$. Selanjutnya, jamu disaring dengan kain blacu untuk memisahkan filtrat dengan ampas. Filtrat jamu dikeringkan menggunakan vacuum dryer. Ekstrak kering masing-masing formula ditentukan rendemennya.
Uji Toksisitas Formula Jamu dengan Metode brine shrimp lethality test (BSLT).

Ekstrak masing-masing formula jamu dilarutkan dalam air laut dengan konsentrasi 2000 ppm. Selanjutnya larutan tersebut dibuat deret konsentrasi 10, 50, 100, 500, dan 1000 ppm yang digunakan sebagai larutan uji. Larutan sampel dengan deret konsentrasi tertentu dimasukkan Larva udang $A$. Salina L sebanyak 10 ekor pada lubang plate well. Pengujian ini dilakukan sebanyak 3 kali ulangan pada tiap deret konsentrasi. Larutan uji diinkubasi selama 24 jam lalu jumlah larva udang yang mati dihitung untuk menetukan nilai mortalitasnya. Penentuan Mortalitas dan $\mathrm{LC}_{50}$ menggunakan piranti lunak IBM SPSS statistics version 22.

\section{Analisis Sidik Jari Jamu Secara KLT dengan Instrumen CAMAG Linomat 5}

Ekstrak kering jamu dilarutkan dengan metanol PA untuk memeroleh larutan ekstrak dengan konsentrasi 2000 ppm. Larutan ekstrak disaring lalu ditotolkan pada pelat KLT GF254 dengan bantuan alat CAMAG Linomat 5 menggunakan syringe $100 \mu \mathrm{L}$. Parameter penotolan, yaitu volume injeksi 30-35 $\mu \mathrm{L}$, dosage speed $50 \mathrm{~nL} / \mathrm{s}$, dan lebar pita $6.0 \mathrm{~mm}$ (Habibie 2014). Sebanyak $10 \mathrm{~mL}$ fase gerak disiapkan sesuai komposisi 1, komposisi 2 dan komposisi 3 lalu dimasukkan ke dalam bejana kromatografi dan dijenuhkan 30 menit. Kemudian pelat KLT dimasukkan ke dalam bejana berisi fase gerak tersebut. Elusi dihentikan ketika fase gerak telah mencapai $0.5 \mathrm{~cm}$ dari tepi atas pelat KLT. Setelah elusi selesai, pelat diangkat, dikeringkan dan dideteksi pada instrumen CAMAG pada sinar UV $254 \mathrm{~nm}$ dan $366 \mathrm{~nm}$.

Komposisi 1 : Kloroform : aseton : asam format (10:2:1) (Kemenkes RI 2009 dalam Farmakope Herbal Indonesia)

Komposisi 2 : Kloroform : metanol (9:1) (Kemenkes RI 2009 dalam Farmakope Herbal Indonesia)

Komposisi 3 : Kloroform : etil asetat (0.5:0.5) (Yonanda 2011)

\section{Analisis Digital Terhadap Sidik Jari KLT Ekstrak Formula Jamu dengan Perangkat Lunak ImageJ}

Perangkat lunak ImageJ dibuka lalu dipilih menu File-Open. Lalu pilih gambar KLT yang telah didokumentasikan dengan CAMAG Reprostar 3 dengan format.jpg. Menu Rectangular diaktifkan lalu blok pada gambar target yang akan dianalisis, dipilih menu Analyze-Gels-Select First Lane. Gambar diatur 
kontrasnya dengan cara memilih menu Image-typepilih RGB colour, lalu Adjust dan atur Brightness dan Contrast sesuai kebutuhan sampai didapat gambar titik yang jelas. Kemudian dipilih kembali menu AnalyzeGels-plot line, maka akan muncul kurva densitogram yang sesuai dengan gambar KLT. Kurva densitogram ini akan menunjukkan jumlah pita yang terdapat pada pelat KLT. Kurva tersebut kemudian diubah menjadi Line Graph dengan cara menu Rectangular diaktifkan lalu blok pada bagian kurva, kemudian pilih menu Analyze-Tools-Analyze line graph sehingga akan muncul tampilan kurva dalam bentuk kurva XYcoordinat. Lalu pilih menu Copy untuk merubah gambar menjadi informasi dalam bentuk angka. Kemudian paste pada piranti lunak MS.Exel untuk pengolahan kurva selanjutnya.

Menentukan luas puncak densitogram, dibuka kurva densitogram kemudian dipilih salah satu puncak kurva dan menu Straight diaktifkan lalu ditarik bagian dasar puncak ujung satu ke ujung lainnya (Jika terdapat beberapa puncak kurva buat garis dasar pada masingmasing puncak kurva), kemudian menu Wand diaktifkan. Masing-masing daerah puncak kurva diberi Highlight dengan mengarahkan kursor dan memilih pada daerah kurva tersebut, kemudian akan muncul Report berupa luas puncak.

\section{Analisis Data}

Untuk optimasi variabel respon dilakukan dengan menggunakan Design Expert 7.0 ${ }^{\circledR}$. Analisis dilakukan setelah input data hasil respon (LC50) dari formulasi. Analisis ANOVA dapat dilakukan untuk melihat perbedaan nyata yang terdapat pada variabel respon pada selang kepercayaan $95 \%$. Hasil analisis respon bernilai tidak berbeda nyata pada selang kepercayaan 95\% jika memiliki nilai $P$ lebih kecil dari $\alpha=0.05$. Respon yang memiliki nilai analisis ragam tidak berbeda nyata dapat digunakan sebagai model prediksi dalam tahap optimasi.

Optimasi formula dilakukan dengan memilih Optimization pada piranti lunak. Pada bagian Optimization dibagi menjadi tiga bagian, yaitu Numerical Optimization, Graphical Optimization, dan Point Prediction. Pada bagian Optimization terdapat solusi formula optimum yang disarankan program Design Expert $7.0^{\circledR}$.

\section{HASIL DAN PEMBAHASAN}

\section{Prediksi Formula Jamu Baru sebagai Antidiabetes}

Formulasi jamu baru sebagai antidiabetes pada penelitian ini dilakukan menggunakan metode statistika (PLS-DA dan koefisien PLS multiways), dan metode machine lerning (support vector machine (SVM)). Prediksi khasiat formula jamu tersebut menampilkan respon efikasi jamu. Efikasi jamu ini secara ilmiah ditentukan dengan pemodelan komposisi jamu melalui perhitungan data statistik. Data yang digunakan merupakan data jamu yang terdaftar di badan pengawas obat dan makanan (Badan POM), yaitu berjumlah 3138 jamu dengan 465 jenis tanaman. Namun, berdasarkan Afendi (2010) data tersebut direduksi menjadi 2748 jamu yang terdiri atas 231 jenis tanaman, hal ini disebabkan data tersebut telah dianggap cukup untuk mewakili data analisis. Jumlah data yang sangat besar antara jenis tanaman dan jumlah jamu akan menyebabkan multikolinearitas sehingga mengakibatkan regresi menjadi tidak stabil. Maka dari itu, ketiga metode ini dipilih sebagai metode penentuan efikasi untuk prediksi khasiat jamu antidiabetes. Selain itu metode ini juga sangat berguna ketika peubah prediktor yang digunakan dalam model jumlahnya sangat besar.

Model regresi linear PLS-DA dirancang oleh Afendi (2010) untuk menentukan prediksi efikasi jamu baru antidiabetes. Pemodelan PLS-DA ini menghasilkan regresi linear antara khasiat jamu dengan tanaman herbal, yaitu variabel $y$ sebagai khasiat jamu dan variabel $x$ sebagai tanaman herbal. Prediksi khasiat formula jamu baru menggunakan metode PLS-DA merupakan hasil perkalian antara nilai koefisien variabel $x$. Hasil yang diperoleh merupakan respon dari 9 khasiat jamu, yaitu variabel $y$. Respon khasiat jamu yang memiliki nilai koefisien terbesar dipilih sebagai formula jamu khasiat terpilih. Prediksi menggunakan metode koefisien PLS yang dirancang oleh Afendi (2010) digunakan dengan menjumlahkan koefisien dari masing-masing tanaman herbal berdasarkan aktivitas farmakologisnya. Hasil prediksi ini juga menghasilkan nilai respon berupa koefisien terhadap khasiat jamu baru. Nilai koefisien PLS-DA terbesar pada khasiat tersebut yang menjadi respon terpilih.

Berbeda dengan kedua metode tersebut metode machine learning, yaitu SVM tidak menghasilkan nilai respon khasiat berupa koefisien. Metode SVM didasarkan pada pengelompokan data menggunakan data latih untuk membentuk model. Data yang memiliki

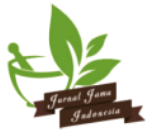


khasiat yang sama akan berkelompok pada daerah komposisi tertentu (Fitriawan 2013). Data 150 formula jamu baru yang diprediksi diuji ke dalam model yang telah dibuat tersebut untuk ditentukan khasiatnya sesuai kelompok daerah komposisinya. Daerah komposisi model yang terdekat dengan formula jamu baru merupakan prediksi khasiatnya.

Sebanyak 150 formula jamu baru dibuat secara manual, yang sebelumnya dilakukan pengelompokan tanaman berkhasiat gastrointestinal disorders (GST) kedalam aktivitas farmakologis analgesik, antibakteri, dan antiinflamasi. Pengelompokan ini sesuai dengan hipotesis yang diajukan pusat studi biofarmaka (PSB), bahwa formula jamu terdiri atas 4 tanaman termasuk tanaman utama. Tanaman utama yang digunakan adalah brotowali (Tinospora tuberculata). Khasiat GST dipilih karena aktivitas farmakologi antidiabetes termasuk kedalam khasiat GST. Dari 150 formula jamu baru diperoleh 7 formula jamu baru berkhasiat GST, yaitu Jamu baru 25, 87, 88, 115, 132, 133, dan jamu baru 142 (Tabel 1). Tujuh formula jamu terpilih tersebut yang mempunyai khasiat GST berdasarkan hasil ketiga metode tersebut.

Kandidat jamu baru khasiat antidiabetes terpilih berdasarkan ketiga metode yang digunakan (Tabel 1). Dari tujuh kandidat jamu baru tersebut kemudian dipilih berdasarkan urutan peringkat nilai respon terbesar sampai terkecil. Jika dilihat dari hasil PLS peringkat dengan nilai respon terbesar adalah jamu baru ke 142, sedangkan untuk metode multiway nilai respon terbesar adalah jamu baru ke 88. Hal ini tidak ada kecocokan peringkat yang sama pada kandidat formula jamu tersebut. Maka dari itu dipilih untuk metode PLS dan multiway dari nilai respon terbesar kedua, yaitu jamu baru ke 87. Baik metode PLS, maupun multiway keduanya memiliki peringkat nilai respon yang sama. Namun jamu baru ke 87 tidak dipilih sebagai kandidat jamu baru khasiat antidiabetes pada penelitian ini, hal ini disebabkan oleh terdapatnya komponen tanaman yang sulit ditemukan, yaitu buah merah (Phaleria papuana). Pemilihan kandidat jamu selanjutnya diturunkan pada nilai respon terbesar ketiga untuk metode PLS, dan nilai respon terbesar pertama untuk metode multiway, yaitu kandidat jamu ke 88 . Jamu baru ke 88 terdiri atas 4 tanaman, yaitu brotowali (Tinospora tuberculata) sebagai tanaman utama, kayu secang (Caesalpinia sappan) sebagai analgesik, jambu biji (Psidium guajava) sebagai antibakteri, dan sambiloto (Andrographis paniculata) sebagai antiinflamasi. Keempat tanaman terpilih dengan bagian tanaman yang digunakan mempunyai kandungan bahan aktif yang memiliki efek farmakologi hipoglikemik (mampu menurunkan kadar gula darah). Dari keempat tanaman hasil prediksi, dua di antaranya memiliki efek tersebut, yaitu brotowali (Tinospora tuberculata) dan sambiloto (Andrographis paniculata) (Sriyapai et al. 2009). Hal inilah yang mendasari pemilihan brotowali sebagai tanaman utama dalam formulasi jamu antidiabetes. Meskipun sambiloto memiliki efek farmakologi hipoglikemik, dalam penelitian ini sambiloto digunakan sebagai tanaman pendukung antiinflamasi. Sedangkan 2 tanaman lainnya, yaitu secang (Caesalpinia sappan) dan Jambu biji (psidium guajava) memiliki efek farmakologi pendukung.

Tanaman- tanaman yang digunakan memiliki banyak kandungan senyawa kimia yang bermanfaat dalam proses penurunan kadar gula darah. Kandungan senyawa batang brotowali terdiri atas alkaloid, glikosida pikroretosida, pati, palmatin, zat pahit dan barberin (Sari 2014). Kandungan senyawa sambiloto meliputi flavonoid, diterpenoid, andografolid, xanton, dan asam quinik (Hossain et al. 2014). Kandungan senyawa daun jambu biji meliputi polifenol, tanin,

Tabel 1 Kandidat formula jamu khasiat antidiabetes

\begin{tabular}{|c|c|c|c|c|c|}
\hline \multirow{2}{*}{ Kode Jamu } & \multicolumn{2}{|c|}{ PLS } & \multicolumn{2}{|c|}{ Multiway } & \multirow{2}{*}{$\begin{array}{c}\text { SVM } \\
\text { Efikasi }\end{array}$} \\
\hline & Efikasi & Nilai respon & Efikasi & Nilai respon & \\
\hline $\mathrm{Jb} 25$ & GST & 0.40921 & GST & 0.23943 & GST \\
\hline $\mathrm{Jb} 87$ & GST & 0.81721 & GST & 0.30614 & GST \\
\hline $\mathrm{Jb} 88$ & GST & 0.76578 & GST & 0.30789 & GST \\
\hline $\mathrm{Jb} 115$ & GST & 0.28323 & GST & 0.17856 & GST \\
\hline Jb132 & GST & 0.41173 & GST & 0.19488 & GST \\
\hline $\mathrm{Jb} 133$ & GST & 0.48771 & GST & 0.30196 & GST \\
\hline Jb142 & GST & 0.83091 & GST & 0.13636 & GST \\
\hline
\end{tabular}

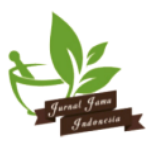


flavonoid dan asam guajaverin (Fernandes et al. 2014). Sedangkan kandungan senyawa secang meliputi brazilein, saponin dan minyak atsiri seperti $D-\alpha-$ felandrena, asam galat, osinema, dan damar. Selain itu brazilein dalam secang memiliki aktivitas antioksidan dan memiliki aktivitas antikanker (Liang et al. 2014).

Kandungan senyawa yang terdapat dalam keempat tanaman tersebut memiliki manfaat masing-masing, di antaranya senyawa alkaloid yang terdapat dalam batang brotowali dapat menurunkan kadar glukosa darah dan bermanfaat sebagai antioksidan, antikanker, antibakteri, serta antiinflamasi. Tanin yang banyak terkandung dalam daun jambu biji bermanfaat sebagai antibakteri (Fernandes et al. 2014). Flavonoid dalam sambiloto dapat menurunkan kadar glukosa darah dan bermanfaat sebagai antioksidan, antikanker, antibakteri (Rahman et al. 2014), dan antiinflamasi. Senyawa-senyawa tersebut yang diharapkan merupakan senyawa target yang dapat membantu menurunkan kadar gula darah dalam formula jamu terpilih.

\section{Formulasi Jamu Baru Terpilih Menggunakan Piranti Lunak Design Expert 7.0}

Formula jamu yang telah dipilih kemudian dirancang komposisinya menggunakan Design Expert versi $7.0^{\circ}$ dengan model mixture - simplex latice yang menghasilkan beberapa formula dengan berbagai komposisi. Mixture design digunakan saat suatu sistem terdiri atas campuran beberapa komponen yang jumlah totalnya konstan, yaitu $100 \%$. Respon yang diperoleh merupakan fungsi dari proporsi relatif tiap komponen dalam sistem bukan karena jumlah campuran (Cornel J A 1990). Pada mixture design dapat digunakan dua komponen atau lebih. Bertambahnya jumlah komponen yang terlibat akan menambah jumlah dimensi ruang yang dipakai dalam menggambarkan mixture. Saat dua komponen terlibat maka profil campuran akan mengikuti garis lurus, saat tiga komponen akan berbentuk segitiga, berbentuk tetrahedron saat empat komponen digunakan, dan seterusnya. Objek paling sederhana yang menggambarkan dimensi mixture disebut sebagai simplex.

Saat digunakan tiga komponen atau lebih, mixture design dapat mengikuti rancangan simplex-lattice, simplex-centroid, maupun simplex-centroid dengan axial design. Pada rancangan campuran berbentuk simplex-lattice titik-titik yang digunakan tersebar disepanjang sisi simplex. Jika diamati lebih lanjut rancangan ini fokus pada pengaruh komponen tunggal dan kombinasi dua komponen atau lebih dengan berbagai variasi proporsi terhadap respon yang dihasilkan (Wahyuni S 2010). Berdasarkan hal tersebut, dalam pembuatan formula jamu ini, digunakan rancangan desain mixture- simplex lattice. Dengan pegaruh komponen tunggal, yaitu batang brotowali (Tinospora tuberculata) sebagai tanaman utama, dan tiga komponen lainnya, sambiloto (Andrographis paniculata), secang (Caesalpinia sappan), dan jambu biji (psidium guajava), serta nilai $\mathrm{LC}_{50}$ sebagai variabel respon.

Hasil desain formula jamu diperoleh sebanyak 12 desain kemudian dirangkum menjadi 9 formula jamu seperti yang tercantum pada Tabel 2. Sebelum diekstraksi, setiap bagian tanaman dibersihkan dengan air mengalir dan dikeringkan dengan cara kering udara dan pemanasan oven pada suhu $50^{\circ} \mathrm{C}$. Simplisia digiling dengan ukuran 40 mesh. Penggilingan bahan uji dilakukan untuk menyeragamkan ukuran bahan agar

Tabel 2 Desain formula jamu baru antidiabetes

\begin{tabular}{ccccc}
\hline \multirow{2}{*}{ Formula jamu } & \multicolumn{3}{c}{ Tanaman } \\
\cline { 2 - 5 } & $\begin{array}{c}\text { Brotowali } \\
\text { (gram) }\end{array}$ & $\begin{array}{c}\text { Kayu Secang } \\
\text { (gram) }\end{array}$ & $\begin{array}{c}\text { Jambu Biji } \\
\text { (gram) }\end{array}$ & $\begin{array}{c}\text { Sambiloto } \\
\text { (gram) }\end{array}$ \\
\hline F1 & 1.000 & 0.000 & 9.000 & 0.000 \\
F2 & 10.000 & 0.000 & 0.000 & 0.000 \\
F3 & 1.000 & 9.000 & 0.000 & 0.000 \\
F4 & 1.000 & 0.000 & 0.000 & 9.000 \\
F5 & 2.125 & 5.625 & 1.125 & 1.125 \\
F6 & 3.250 & 2.250 & 2.250 & 2.250 \\
F7 & 6.625 & 1.125 & 1.125 & 1.125 \\
F8 & 2.125 & 1.125 & 5.625 & 1.125 \\
F9 & 2.125 & 1.125 & 1.125 & 5.625 \\
\hline
\end{tabular}


proses ekstraksi semakin efisien, karena semakin seragam ukuran bahan uji, akan semakin mudah terjadi interaksi antara bahan uji dan pelarut.

Ekstraksi formula jamu baru dilakukan dengan metode penggodokan sesuai dengan metode tradisional dalam pembuatan jamu gendong. Ekstraksi yang dilakukan menggunakan akuabides, hal ini disebabkan oleh akuabides merupakan pelarut yang aman digunakan untuk pembuatan jamu. Selain itu akuabides juga merupakan pelarut yang steril, sehingga diharapkan dapat menghasilkan ekstrak yang lebih baik. Ekstrak cair yang diperoleh kemudian dikeringkan menggunakan vaccum dryer. Ekstrak kering setiap formula jamu kemudian ditentukan persen rendemennya. Ekstrak kering memiliki warna yang berbeda, yaitu coklat sampai merah bata kehitaman.

\section{Uji Toksisitas Formula Jamu Menggunakan Metode Brine Shrimp Lethality Test (BSLT)}

Uji toksisitas senyawa metabolit ekstrak formula jamu kering dilakukan dengan metode BSLT menggunakan larva udang $A$. Salina L. Uji toksisitas merupakan salah satu tahapan dalam pengujian farmakologi eksperimental. Metode ini dipilih berdasarkan beberapa alasan, yaitu pengerjaannya relatif mudah, dan tidak mahal serta tidak membutuhkan sesuatu yang khusus dalam pengerjaannya. Selain itu, metode ini menghasilkan tingkat kepercayaan 95\% untuk mengamati toksisitas suatu ekstrak kasar suatu tanaman (Vivi et al. 2006).
Berdasarkan hasil perhitungan diperoleh nilai $\mathrm{LC}_{50}$ (lethal concentration) ekstrak formula jamu sebagai ekstrak uji. LC $_{50}$, yaitu konsentrasi ekstrak uji yang menyebabkan kematian larva udang sejumlah $50 \%$ setelah inkubasi 24 jam. Perhitungan $\mathrm{LC}_{50}$ dilakukan menggunakan piranti lunak IBM SPSS statistics version 22 dengan parameter perhitungan analisis probit dilanjutkan dengan analisis One-way-Anova lalu diuji lanjut menggunakan uji Duncan.

Hasil perhitungan rerata nilai $L_{50}$ dari 9 formula jamu dengan selang kepercayaan $95 \%$ dapat dilihat dari Gambar 1. Nilai $\mathrm{LC}_{50}$ pada masing-masing formula jamu memiliki nilai yang beragam. Hal ini disebabkan oleh perbedaan komposisi antar tanaman yang memungkinkan memiliki toksisitas yang berbeda pula. $\mathrm{Hal}$ ini akan berpengaruh terhadap kandungan senyawa metabolit tanaman. Nilai LC $_{50}$ besar memilki tingkat toksisitas formula jamu rendah dan menunjukan keamanan formula jamu untuk dikonsumsi. Formula jamu yang memiliki toksisitas tinggi adalah formula jamu 8 dengan rerata nilai LC $_{50}$ sebesar 426 ppm sedangkan formula jamu yang memiliki toksisitas rendah adalah formula jamu 6 dengan rerata nilai $L_{50}$ sebesar 639 ppm. Hasil menunjukkan bahwa nilai LC $_{50}$ setiap ulangan pada setiap formula jamu beragam sehingga perlu dilakukan ANOVA. Hasil ANOVA pada penelitian ini berbeda nyata pada selang kepercayaan 95\% sehingga dilakukan analisis lanjut dengan metode Duncan.

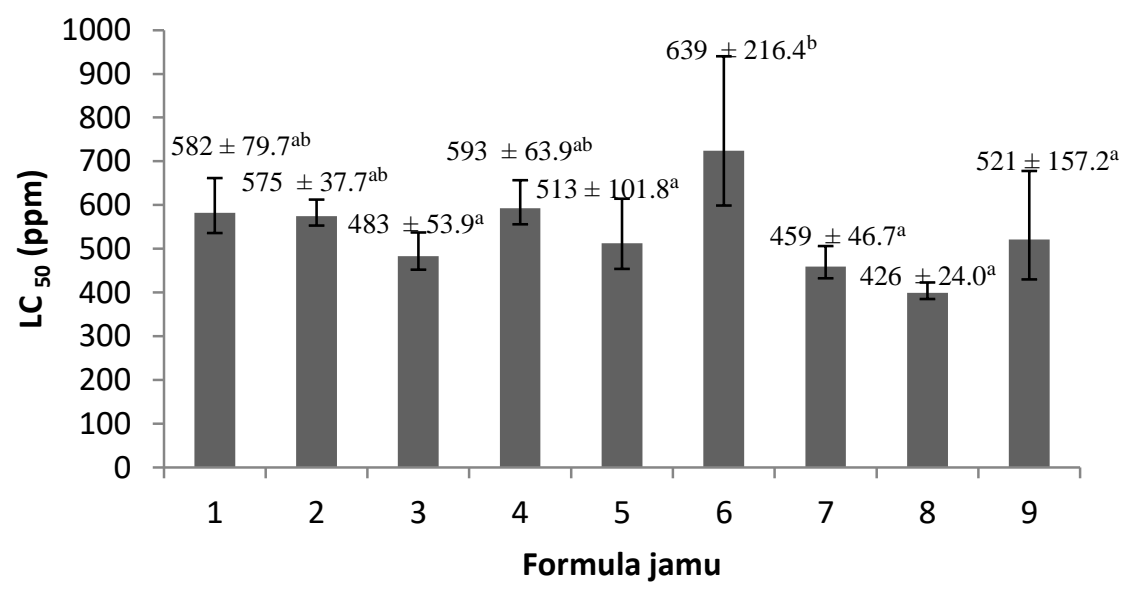

Nilai yang disertai dengan huruf superscripts yang sama tidak berbeda nyata pada $\alpha=0.05$ (Duncan's multiple range test)

Gambar 1 Rerata Nilai LC50 formula jamu antidiabetes

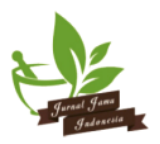


Dari hasil perhitungan, menunjukkan bahwa 9 formula jamu tersebut memiliki tingkat keamanan yang baik untuk dikomsumsi sebagai jamu, karena nilai $\mathrm{LC}_{50}$ yang diperoleh masing-masing formula jamu dibawah 1000 ppm. Hal ini menunjukkan bahwa 9 formula jamu termasuk kedalam kategori toksik sedang atau menengah, karena nilai $\mathrm{LC}_{50}$ yang diperoleh berada di rentang 30 sampai 1000 ppm (Mayer et al. 1982). Dengan demikian formula jamu yang dirancang dan diprediksi sebagai jamu antidiabetes dapat memiliki potensi sebagai jamu antidiabetes yang aman digunakan dan terus dikembangkan.

\section{Optimasi Formula Jamu}

Hasil pengukuran respon $\left(\mathrm{LC}_{50}\right)$ kemudian diinput dan dianalisis menggunakan program Design Expert $7.0^{\circ}$. Hasilnya berupa model polinomial yang sesuai dengan data respon. Rancangan Mixture-simplex lattice terdiri atas lima jenis model polinomial, yaitu mean, linear, quadratic, cubic, dan special cubic. Salah satu model tersebut akan direkomendasikan oleh program sebagai model yang sesuai atau mewakili data respon. Pada bagian Analisys terdapat menu Fit summary yang menampilkan informasi model yang direkomendasikan program. ANOVA (analisys of variance) berguna untuk memperoleh informasi terkait signifikansi model yang digunakan dengan nilai lack of fit. Model yang diinginkan adalah model yang memiliki signifikansi yang baik dan nilai lack of fit yang tidak signifikan. Selain itu, predicted R-squared dan adjusted $R$-squared harus bersesuaian satu sama lain dengan nilai adequate precision lebih dari empat (Chandra 2011).

Berdasarkan hasil analisis $\mathrm{LC}_{50}$ rentang nilai dari respon yang didapatkan berkisar dari 426-639 ppm . Dari hasil analisis, model polinomial dari respon $\mathrm{LC}_{50}$ adalah linear. Namun model ini memiliki nilai predicted $R$-squared negatif, dan pada ANOVA modelnya tidak signifikan karena nilai $\mathrm{p}$ "prob $>\mathrm{F}$ lebih besar dari $\alpha=0.05$, yaitu 0.4830 . Sehingga dilakukan modifikasi model secara manual dengan cara reduksi model. Model yang tidak signifikan adalah model yang mempunyai nilai $p$ "prob $>F$ " lebih besar dari $\alpha=0.05$. Sedangkan model yang mempunyai nilai $p$ "prob $>F$ " lebih kecil dari $\alpha=0.05$ adalah model yang signifikan atau diharapkan. Berbagai cara reduksi model telah dilakukan namun, nilai predicted $R$-squared tetap memberikan nilai negatif. Tetapi Hasil ANOVA diperoleh nilai yang signifikan, dengan model yang dipilih mixture reduced quadratic model.
Pada model reduced quadratic diperoleh nilai analisis ANOVA yang signifikan dengan nilai $p$ "prob $>F$ " lebih kecil dari $\alpha=0.05$, yaitu 0.0411. Analisis ANOVA juga menunjukan bahwa pada taraf signifikansi $5 \%$ lack of fit dari model yang dihasilkan tidak signifikan, karena nilai $p$ "prob $>F$ " lebih besar dari $\alpha=0.05$, yaitu 0.2491 dengan F-Value 2.36. Nilai lack of fit yang tidak signifikan berarti adanya kesesuaian antara data respon $\mathrm{LC}_{50}$ (ppm) dengan model, yang berarti nilai lack of fit tidak signifikan menggambarkan respon yang baik dengan model.

Salah satu bagian menu dari Analisys dari program Design Expert $7.0^{\circ}$ terdapat bagian diagnostic yang menunjukkan plot kenormalan residual yang menggambarkan titik-titik yang mendekati garis normalnya. Artinya jika titik-titik tersebut semakin mendekati garis maka hasil aktual akan mendekati hasil yang diprediksikan. Selain itu terdiri atas bagian models graphs yang menampilkan grafik berbentuk dua dimensi (Contour plot), atau tiga dimensi (3D). Warna pada contour plot menunjukkan bagaimana interaksi komponen mempengaruhi respon. Gambar 2 menunjukkan grafik kenormalan internally studentized residuals respon $\mathrm{LC}_{50}$ yang diperoleh dari hasil analisis. Pada gambar tersebut tampak bahwa titik-titik yang tersebar berdekatan dengan garis. Sebaran tersebut menunjukkan bahwa adanya pemodelan terhadap asumsi ANOVA pada respon $\mathrm{LC}_{50}$ terpenuhi.

Gambar 3 menunjukkan grafik tiga dimensi dari respon $\mathrm{LC}_{50}$. Bentuk grafik yang bergelombang dipengaruhi oleh model yang digunakan. Ada perbedaan gradasi warna abu-abu sampai hitam. Pada salah satu daerah komponen satu dan komponen lainnya memiliki warna yang sama artinya komponenkomponen tersebut tidak berbeda nyata terhadap respon $\mathrm{LC}_{50}$, sedangkan pada daerah warna komponen yang memiliki warna berbeda artinya komponenkomponen tersebut berbeda nyata dan dapat memiliki pengaruh terhadap respon.

Setelah dilakukan analisis, selanjutnya adalah optimisasi dengan memilih bagian Optimization, dan mulai mengatur kriteria untuk tiap komponen pada bagian Criteria. Komponen yang termasuk variabel berubah diatur agar menjadi kategori in range dengan batas lower dan upper disesuaikan dengan kebutuhan. Pada penelitian ini batas lower dan upper yang digunakan adalah 0 hingga $9 \mathrm{~g}$ untuk tiga komponen berubah, secang, jambu biji, dan sambiloto, sedangkan untuk komponen brotowali, yaitu 1 hingga $10 \mathrm{~g}$. Hal ini

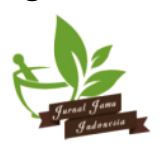



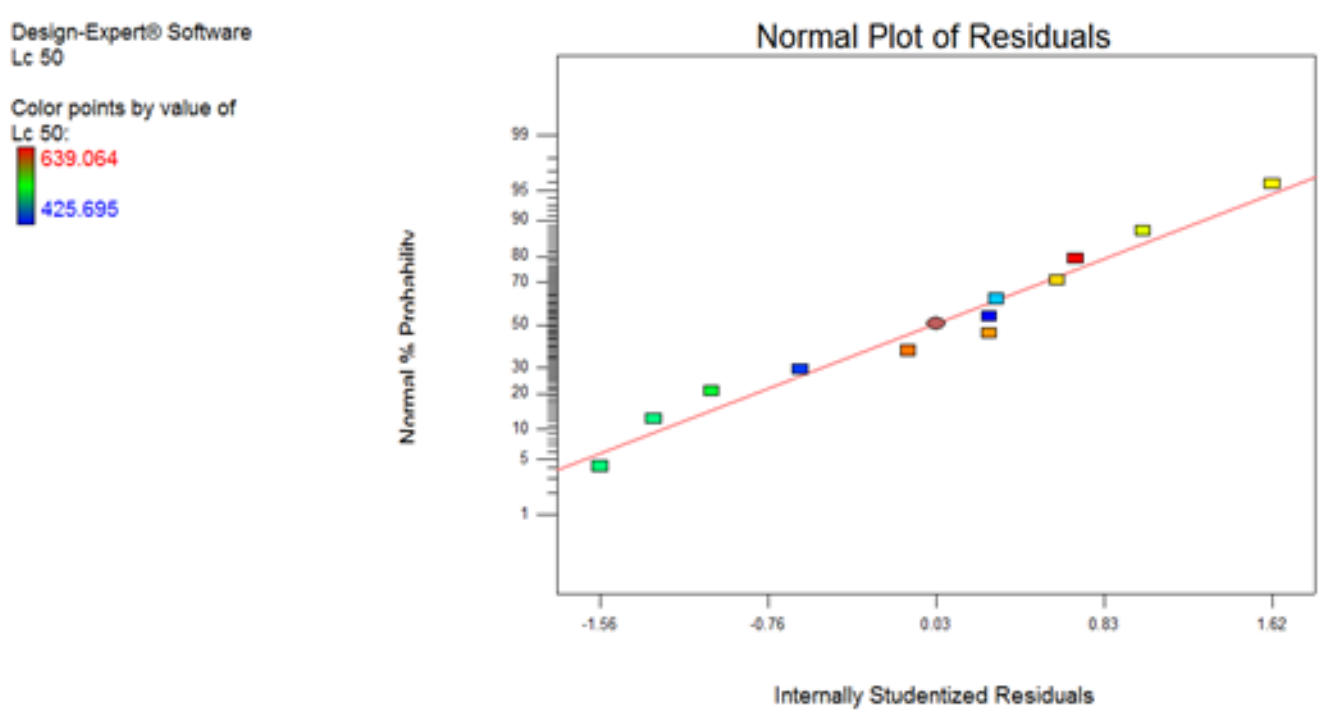

Gambar 2 Kenormalan internally studentized residuals terhadap respon $\mathrm{LC}_{50}$
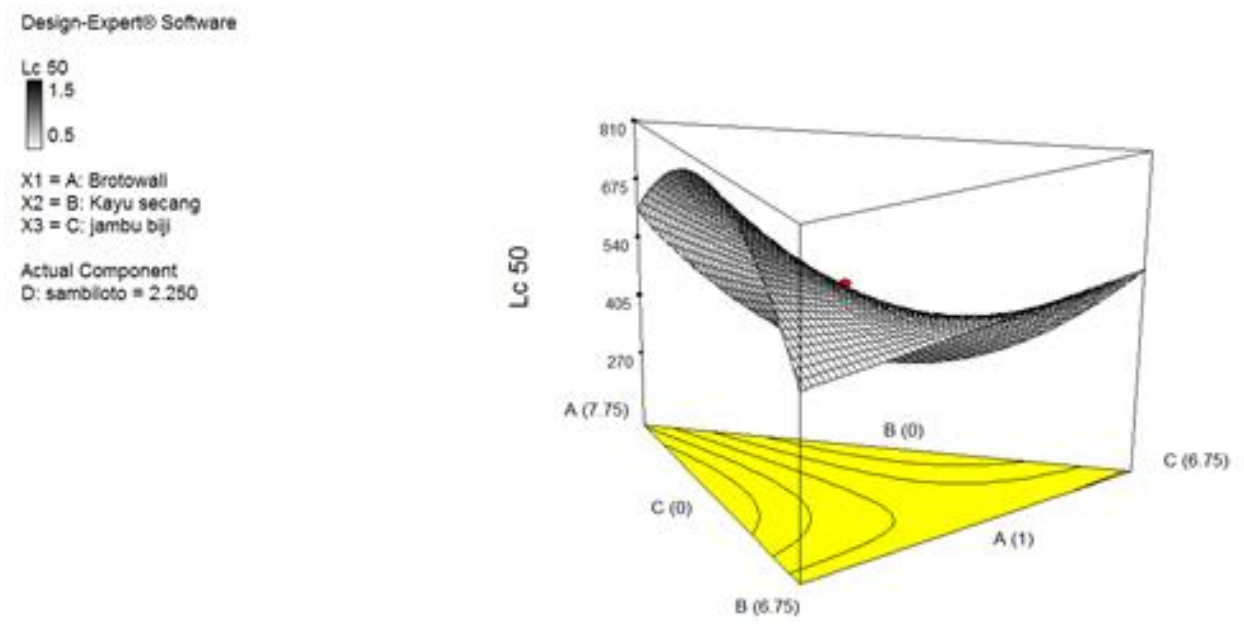

Gambar 3 Grafik tiga dimensi hasil uji respon $\mathrm{LC}_{50}$

disebabkan oleh brotowali sebagai komponen utama yang harus selalu ada dalam setiap formula minimal 1 g. Komponen yang merupakan respon diatur sesuai dengan kebutuhan. Respon yang diinginkan adalah nilai $\mathrm{LC}_{50}$ yang bernilai minimal, karena semakin kecil nilai $\mathrm{LC}_{50}$ maka semakin baik respon yang diharapkan. Pada pengaturan kriteria ini diperlukan juga tingkat importance (kepentingan), yang menunjukkan seberapa penting komponen-komponen dalam mempengaruhi respon. Untuk keempat komponen diberikan tingkat kepentingan tiga nilai, sedangkan untuk respon diberikan tingkat kepentingan lima nilai.

Optimasi ini memberikan solusi, berupa formula optimum yang diprediksi oleh progam Design Expert $7.0^{\circ}$. Diperoleh sebanyak 29 kombinasi formula dengan nilai desirability (keterpilihan) yang cenderung sama. Menurut Wang dan Fang (2010) nilai keterpilihan berkisar diantara 0 sampai 1 , jika nilai respon sama dengan target maka nilai keterpilihannya 1 , tetapi jika nilai respon tidak sama dengan target maka nilai keterpilihannya 0 . Nilai 1 adalah nilai tertinggi dan nilai 0 adalah nilai terendah. Formula yang disarankan dengan nilai keterpilihan tertinggi menempati posisi teratas dari beberapa formula yang diasarankan. Semakin tinggi nilai keterpilihan, maka hasil respon semakin mendekati nilai yang diprediksi. Hal ini menjadi dasar dalam pemilihan formula optimum.

Berdasarkan hasil optimasi terdapat 28 formula yang memiliki nilai keterpilihan 1 dan satu formula yang memiliki nilai keterpilihan 0.8481 . Oleh sebab itu,

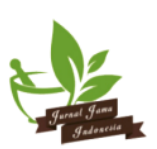


diperlukan seleksi untuk pemilihan satu formula yang dianggap paling optimum. Parameter yang digunakan dalam tahap seleksi ini, yaitu memiliki nilai respon $\mathrm{LC}_{50}$ paling kecil diantara formula yang memiliki nilai keterpilihan 1, formula yang komposisinya mengandung semua komponen, dan formula yang komposisi komponen utamanya lebih banyak dari komponen yang lainnya. Berdasarkan parameter tersebut, maka dipilihlah formula optimum yang disarankan adalah formula ke 14 dengan komposisi brotowali 5.597 gram; secang 3.22 gram; jambu biji

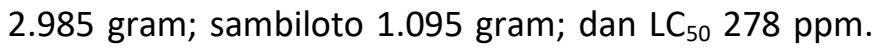
Formula 14 kemudian diekstraksi dan dikeringkan dengan cara yang sama seperti pembutan formula jamu sebelumnya. Ekstrak kering kemudian diuji toksisitasnya menggunakan metode brine shrimp letality test (BSLT). Tujuan dilakukan pengujian ulang terhadap formula optimum yang disarankan adalah mencocokkan nilai prediksi dari respon dengan hasil analisis laboratorium. Hasil uji toksisitas diperoleh nilai $\mathrm{LC}_{50}$ lebih besar dari hasil prediksi, yaitu 456 ppm.

\section{Analisis Profil Kimia Formula Jamu}

Kromatografi lapis tipis (KLT) merupakan salah satu teknik pemisahan. Cuplikan yang akan dipisahkan akan terdistribusi diantara dua fase, yaitu fase diam dan fase gerak sehingga akan terurai menjadi komponenkomponen tunggal (Stoenoiu et al. 2006). Ekstrak kering formula jamu selanjutnya dianalisis sidik jarinya menggunakan metode kromatografi lapis tipis dengan bantuan instrumen CAMAG Linomat 5 . Alat ini dikendalikan oleh mikroprosesor yang menyebabkan larutan ekstrak dapat ditotolkan pada pelat KLT dan biasanya dalam bentuk pita dengan mengkompresikan tekanan udara atau nitrogen sehingga tidak memerlukan kontak langsung pelat dan dapat mengurangi kerusakan alat (Fitrianti 2011).

Analisis sidik jari merupakan suatu metode yang digunakan untuk menampilkan informasi suatu senyawa kimia dalam suatu sampel berupa spektrogram, kromatogram atau bentuk lainnya. Metode sidik jari juga digunakan untuk menentukan senyawa penciri suatu bahan alam berdasarkan bentuk dan pola grafik yang ditunjukkan dalam teknik analisis. Analisis sidik jari menggunakan KLT telah banyak digunakan oleh industri obat di Amerika, Eropa dan Cina karena terdapat beberapa keuntungan, yaitu sederhana, selektif dan sensitif, cepat, biaya relatif murah, dapat mengujikan beberapa sampel dalam waktu bersamaan, kromatogramnya dapat dilihat secara visual dan penggunaan pelarut yang sedikit (Shams et al. 2014).

Hasil menunjukkan pita dengan keterpisahan yang beragam. Keterpisahan pita yang baik diperoleh pada pelat KLT yang dielusi dengan fase gerak komposisi satu. Sedangkan hasil menggunakan fase gerak komposisi dua dan tiga keterpisahanya kurang baik. Kromatogram yang memiliki keterpisahan baik, selanjutnya dianalisis lanjut menggunakan piranti lunak ImageJ. Seperti telah dijelaskan pada paragraf sebelumnya, yaitu analisis sidik jari dapat digunakan untuk menunjukkan informasi senyawa kimia dari suatu sampel berupa spektrogram, kromatogram atau bentuk grafik lain. Dalam penelitian ini dilakukan analisis sidik jari secara densitogram yang merupakan hasil dari pengolahan piranti lunak ImageJ.

ImageJ merupakan suatu piranti lunak untuk pengolah gambar yang berbasiskan program Java dan dapat diperoleh secara bebas untuk umum. Pada prinsipnya ImageJ merupakan piranti lunak yang dapat mengubah citra dari bentuk pita menjadi bentuk densitogram dan terkuantifikasi dengan baik. Selain itu ImageJ juga mampu memperlihatkan besar kecilnya kandungan suatu komponen dalam sampel dengan jelas terutama pada komponen pencirinya (Dewi $R$ 2013). Hasil olahan piranti lunak ImageJ diperoleh jumlah pita yang tercantum dalam Tabel 3.

Tabel 3 Jumlah pita hasil piranti lunak ImageJ

\begin{tabular}{ccc}
\hline \multirow{2}{*}{ Formula jamu } & \multicolumn{2}{c}{ Jumlah Pita } \\
\cline { 2 - 3 } & UV 254 $\mathbf{~ m m}$ & UV $\mathbf{3 6 6} \mathbf{~ n m}$ \\
\hline F1 & 1 & 1 \\
F2 & 5 & 4 \\
F3 & 5 & 5 \\
F4 & 6 & 5 \\
F5 & 5 & 5 \\
F6 & 5 & 6 \\
F7 & 5 & 5 \\
F8 & 5 & 5 \\
F9 & 6 & 5 \\
\hline
\end{tabular}

Jumlah pita yang dihasilkan dibedakan menurut hasil deteksi UV 254 nm dan UV 366 nm. Penyinaran pada UV $254 \mathrm{~nm}$ bertujuan mendeteksi senyawa golongan alkaloid, flavonoid, lignan, dan triterpena berdasarkan pemadamannya (quenching). Sedangkan

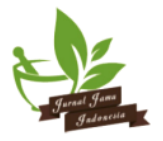


penyinaran pada UV $366 \mathrm{~nm}$ bertujuan mendeteksi golongan yang sama namun berdasarkan pendarannya (fluorescence) (Fernand 2003). Menurut Oktavia (2011) pada umumnya deteksi menggunakan UV 366 nm menghasilkan pita yang lebih jelas dari pada deteksi pada UV $254 \mathrm{~nm}$. Hal ini disebabkan fase diam KLT $\mathrm{GF}_{254}$ terbuat dari silika gel yang akan berpendar pada panjang gelombang tersebut sehingga pita gelap komponen sampel kurang terlihat. Berlainan pada UV $366 \mathrm{~nm}$ pita yang berpendar adalah komponen sampel.

Hasil pembacaan pada fase gerak komposisi 1 umumnya memiliki jumlah pita yang terlihat pada pembacaan UV $254 \mathrm{~nm}$ lebih banyak, dibandingkan jumlah pita yang terlihat pada pembacaan UV $366 \mathrm{~nm}$ (Tabel 3). Hal ini bisa terjadi disebabkan pada pembacaan $366 \mathrm{~nm}$ pita yang berpendar terlalu tipis sehingga tidak dapat terbaca oleh piranti lunak ImageJ sebagai kurva densitogram. Pita-pita pemisahan ekstrak formula jamu tampak sebagai pendaran warna merah dan biru. Pendaran biru muda menunjukkan adanya senyawa flavon, flavonon, atau flavonol. Sedangkan pendaran warna merah menunjukkan adanya senyawa antosianidin (Markham 1988). Profil KLT ekstrak formula jamu yang dielusi menggunakan komposisi 1 yang ditampilkan pada Gambar 4.

Dari Gambar 4 dapat diketahui perbedaan intensitas pendaran warna yang semakin meredup dari formula jamu 3 hingga formula jamu 9. Hal ini dipengaruhi oleh banyaknya komposisi masing-masing tanaman yang digunakan. Dilihat dari keterpisahannya, profil sidik jari KLT menggunakan fase gerak komposisi 1 cukup baik. Namun, ada beberapa pita yang tipis sehingga pada saat dideteksi pada UV $366 \mathrm{~nm}$ tidak terlalu jelas namun terbaca sebagai puncak densitogram. Berarti ada senyawa yang terbawa oleh fase gerak meskipun kadarnya sedikit. Jumlah pita yang diperoleh hasil elusi menggunakan fase gerak komposisi 1 diperkuat dengan kurva densitogram hasil pengolahan piranti lunak ImageJ.

Kurva densitogram yang diperoleh kemudian

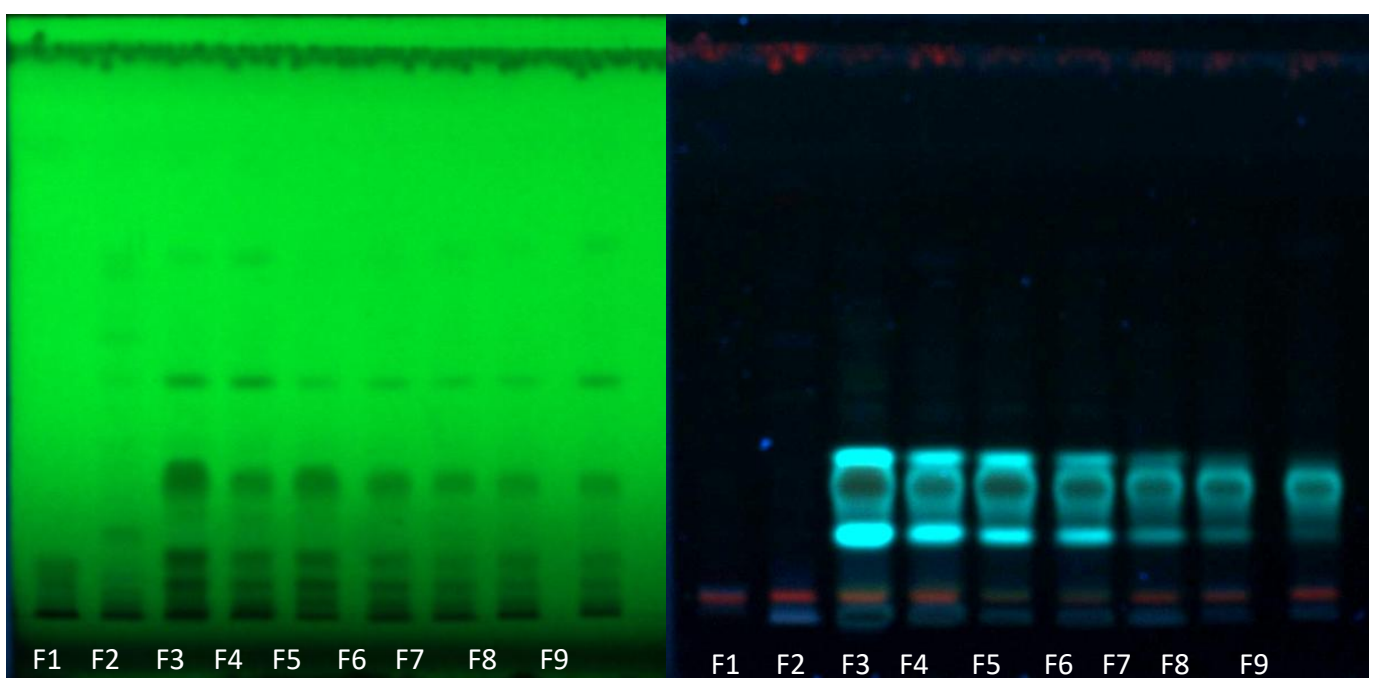

Gambar 4 Profil KLT ekstrak formula jamu 1-9 (F1-F9) fase gerak komposisi 1 (kiri) deteksi UV 254 nm (kanan) deteksi UV $366 \mathrm{~nm}$

Tabel 4. Nilai faktor retensi $(R f)$ dan area kurva densitogram formula jamu 5

\begin{tabular}{cccccc}
\hline & \multicolumn{2}{c}{ Deteksi UV 254 nm } & \multicolumn{3}{c}{ Deteksi UV $\mathbf{3 6 6} \mathbf{~ n m}$} \\
\hline Pita & $\mathbf{R f}$ & Area (Pixel) & Pita & Rf & Area (pixel) \\
\hline 1 & 0.03 & 543.799 & 1 & 0.03 & 863.770 \\
2 & 0.06 & 496.477 & 2 & 0.06 & 809.698 \\
3 & 0.09 & 1.039 .205 & 3 & 0.18 & 7.046 .397 \\
4 & 0.14 & 3.667 .631 & 4 & 0.23 & 1.721 .376 \\
5 & 0.30 & 704.749 & 5 & 0.30 & 11.024 .924 \\
\hline
\end{tabular}


ditentukan area kurva tersebut, yang digunakan untuk melihat banyaknya senyawa yang ikut terbawa dalam masing-masing pita. Semakin besar area kurva maka semakin banyak senyawa yang ikut terbawa dalam pita. Sebagai contoh profil kimia yang diperoleh pada formula jamu 5 (Gambar 5). Angka 1-7 menunjukkan pita-pita pemisahan yang diperoleh. Nilai faktor retensi $(R f)$ dan area kurva densitogram formula jamu 5 tercantum dalam Tabel 4.
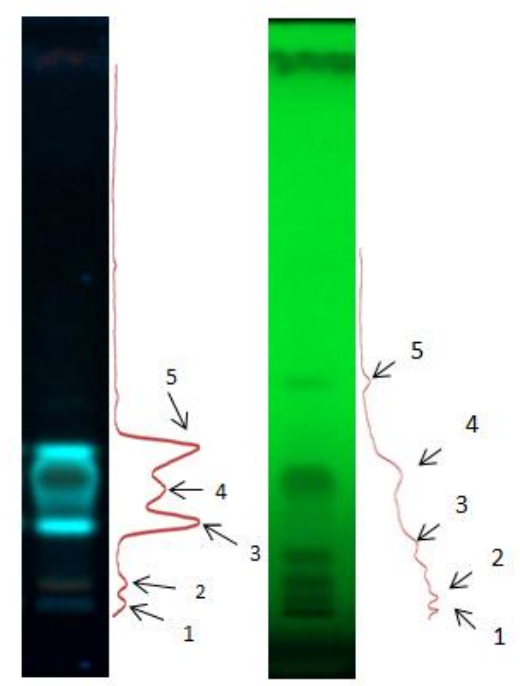

Gambar 5Visualisasi kromatogram formula jamu 5 menggunakan piranti lunak ImageJ deteksi UV 366 nm (Kiri) dan deteksi UV 254 nm (Kanan)

Tabel 4 menjelaskan perbedaan area kurva densitogram pembacaan UV $254 \mathrm{~nm}$ dan UV $366 \mathrm{~nm}$. Area kurva densitogram pembacaan UV 366 nm lebih besar dibandingkan area kurva densitogram pembacaan UV $254 \mathrm{~nm}$, hal ini disebabkan sampel yang terbaca pada pendaran UV $366 \mathrm{~nm}$ lebih jelas dibandingan UV $254 \mathrm{~nm}$. Area kurva besar mempunyai arti kadar senyawa yang terpisahkan pada pita juga besar. Secara keseluruhan sidik jari KLT formula jamu 1 hingga 9, menggunakan fase gerak komposisi 1 menghasilkan keterpisahan yang cukup baik dengan jumlah pita yang relatif banyak.

Profil kimia jamu optimum juga ditentukan menggunakan metode yang sama, dan fase gerak komposisi 1. Dihasilkan sebanyak 6 pita dengan keterpisahan cukup baik. Pita-pita yang muncul dianalisis menggunakan piranti lunak ImageJ dan ditentukan area kurva densitogram serta nilai faktor retensinya ( $R f$ ) (Tabel 5 dan Gambar 6). Berdasarkan Tabel 5 dan Gambar 6, pola keterpisahan dan bentuk kurva densitogram formula jamu optimum hampir sama dengan pola keterpisahan dan bentuk kurva densitogram formula jamu sebelumnya. Angka 1-6 menunjukkan pita-pita pemisahan yang diperoleh. Dilihat dari tinggi dan lebar kurva densitogramnya, profil kimia formula jamu optimum memiliki kurva densitogram yang tinggi dan lebar. Dengan area kurva densitogram yang beragam.

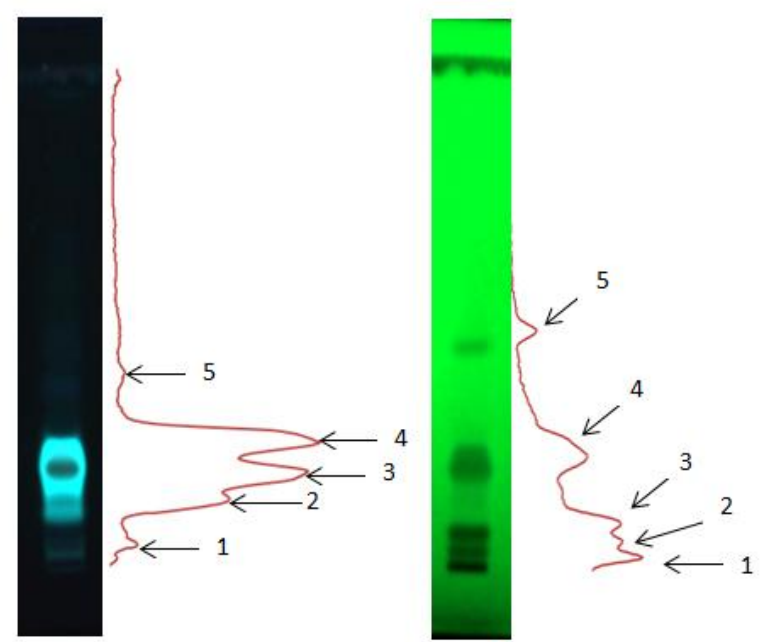

Gambar 6 Visualisasi kromatogram formula jamu Optimum menggunakan piranti lunak ImageJ deteksi UV 366 nm (Kiri) dan deteksi UV 254 $\mathrm{nm}$

Tabel 5 Nilai faktor retensi $(R f)$ dan area kurva densitogram formula jamu optimum

\begin{tabular}{rrrrrr}
\hline \multicolumn{2}{c}{ Deteksi UV 254 nm } & \multicolumn{3}{c}{ Deteksi UV 366 nm } \\
\hline Pita & Rf & Area Kurva (Pixel) & Pita & Rf & \multicolumn{1}{c}{ Area Kurva (Pixel) } \\
\hline 1 & 0.03 & 1.503 .355 & 1 & 0.03 & 936.669 \\
2 & 0.06 & 262.627 & 2 & 0.15 & 1.495 .841 \\
3 & 0.15 & 1.720 .255 & 3 & 0.18 & 4.284 .861 \\
4 & 0.23 & 5.375 .045 & 4 & 0.27 & 9.298 .024 \\
5 & 0.47 & 1.467 .770 & 5 & 0.35 & 384.335 \\
\hline
\end{tabular}




\section{SIMPULAN}

Pembuatan formula jamu berpotensi antidiabetes diformulasi melalui metode statistika dan machine learning dapat dilakukan. Empat tanaman yang diperoleh dari hasil prediksi, yaitu brotowali (Tinospora tuberculata) sebagai tanaman utama, secang (Caesalpinia sappan) sebagai analgesik, jambu biji (Psidium guajava) sebagai antibakteri dan sambiloto (Andrographis paniculata) sebagai antiinflamasi. Setiap formula dapat ditentukan profil kimianya mengunakan metode kromatografi lapis tipis. Dan dapat ditentukan toksisitasnya dengan nilai $L_{50}$ setiap formula sebagai respon untuk menentukan formula optimum. Formula optimum diperoleh menggunakan program Design Expert $7.0^{\circ}$ dengan komposisi brotowali 5.597 gram; secang 3.22 gram; jambu biji 2.985 gram; sambiloto 1.095 gram; dan $\mathrm{LC}_{50} 456$ ppm. Dengan nilai $\mathrm{LC}_{50}$ lebih kecil dari 1000 ppm, dengan demikian formula jamu optimum berpotensi sebagai jamu antidiabetes.

\section{DAFTAR PUSTAKA}

Afendi FM, Darusman LK, Hirai A, Amin MA, Takahashi H, Nakamura K, Kanaya S. 2010. Modelling ingredient of jamu to predict its efficacy. Forum statistika dan komputasi. 15(2).

Afendi F M, Darusman L K, Fukuyama M, Md. Altaf-UIAmin, and Kanaya S. 2012. A Bootstrapping approach for investigating the consistency of assignment of plants to jamu efficacy by PLS model. Malaysian Journal of Mathematical Sciences.6(2):147-164.

Andriana IP. 2014. Formulasi jamu baru antikolesterol melalui studi bioinformatika pangkalan data jamu dengan ikan zebra sebagai hewan model [skripsi]. Bogor (ID): Institut Pertanian Bogor.

[AOAC] Assosiation of Official Analitycal Chemist. 2007. Official Methods of AOAC International. Revisi ke-2 Volume ke-1. Maryland: AOAC International.

Chandra T.2011. Studi pengaruh jenis bahan pengisi terhadap kelekatan bahan seasoning pada produk kacang oven di PT Tudung Putra-Putri Jaya [Skripsi]. Bogor(ID): Institut Pertanian Bogor.

Cornell JA. 1990. Experiments with Mixtures: Designs, Models, and The Analysis of Mixture Data. 2nd ed. New York: John Wiley\&Sons

Dewi R. 2013. Bioaktivitas buah kawista (Limonia acidissima) bima dan penentuan sidik jarinya menggunakan kromatografi lapis tipis [Skripsi]. Bogor (ID): Institut Pertanian Bogor.
Fernand VE. 2003. Initial characterization of crude from Phyllanthus amarus Schum and Thonn. and Quassia amara L. Using normal phase thin layer chromatography [tesis]. Lousiana: University of Suriname.

Fernandes MRV, Azzolini AECS, Martinez MLL, Souza CRF, Valim, Oliveira. 2014. Assessment of antoiksidant activity of spray dried extracts of Psidium gujava leaves by DPPH and chemiluminescience inhibition in human neutrophils. Hindawi Publishing Corporation.doi: $10.1155 / 2014 / 382891$.

Fitrianti SA. 2011. Diferensiasi temulawak, kunyit dan bangle berdasarkan interpretasi kromatografi lapis tipis menggunakan ImageJ [Skripsi]. Bogor (ID): Institut Pertanian Bogor.

Fitriawan A. 2013. Sistem klasifikasi khasiat formula jamu dengan metode support vector machine [skripsi]. Bogor (ID): Institut Pertanian Bogor.

Habibie H. 2014. Pengujian in vivo terhadap efikasi formula jamu antidiabetes dan analisis sidik jari kromatografinya [Skripsi]. Bogor (ID): Institut Pertanian Bogor.

Hossain MDS, Urbi Z, Sule A, Rahman MH. 2014. Andrographis paniculata (Burm.f.) wal. Ex ness: a review of ethnobotany, phytochemistry, and pharmacology. Hindawi Publishing Corporation. doi: 10.1155/2014/274905.

[KEMENKES RI] Kementrian Kesehatan Republik Indonesia. 1994. Persyaratan Obat Tradisional. Jakarta (ID): KEMENKES.

[KEMENKES RI] Kementrian Kesehatan Republik Indonesia. 2009. Keputusan Menteri Kesehatan Republik Indonesia Nomor 261/MENKES/SK/IV/2009 Tentang Farmakope Herbal Indonesia Edisi Pertama. Jakarta (ID): KEMENKES RI.

Liang Hua C et al. 2013. Brazilein from Caesalpinia sappan L. Antioxidant inhibits adipocyte differentiation and induce apoptosis trough caspase-3 activity and anthelmintic activities againts hymenolepis nana and anisakis simplex. Hindawi publishing corporation. doi: 10.1155/2013/864892.

Markham KR. 1988. Cara Mengidentifikasi Flavonoid. Padmawinata K, Penerjemah. Bandung (ID): Penerbit ITB. Terjemahan dari: Techniques of Flavonoid Identification. 
Mayer BN, Ferrigni NR, Putnam JE, Jacobsen LB, Nichols DE, McLaughlin JL. 1982. Brine shrimp: A convenlent general bioassay for active plant constituents. J Med Plant Research 45: 31-34.

Nurishmaya M. 2014. Pendekatan bioinformatika formulasi jamu baru berkhasiat antidiabetes dengan zebrafish (danio rerio) sebagai hewan model [Skripsi]. Bogor (ID): Institut Pertanian Bogor.

Oktavia JD. 2011. Pengoptimuman ekstraksi flavonoid daun salam (Syzygium polianthum) dan analisis sidik jari dengan kromatografi lapis tipis [Skripsi]. Bogor (ID): Institut Pertanian Bogor.

Rahman MM, Ahmad HS, Mohammed MTM, and Rahman Ab ZM. 2014. Antimicrobial compounds from leaf ekstract of Jatropha curcas, Psidium guajava, and Andrographis paniculata. Hindawi publishing corporation. doi: 10.1155/2014/635240.

Ristyawan Y. 2014. Sistem klasifikasi khasiat formula jamu dengan metode voting feature interval 5[Skripsi]. Bogor (ID): Institut Pertanian Bogor.

Sari N. 2014. Farmakologi balik dan jejaring untuk pencarian senyawa aktif dari jamu antidiabetes [Skripsi].Bogor(ID): Institut Pertanian Bogor.

Shams, Ismail, Chee TL, Ali AM, Majid FAA, et al. 2014. Development of HPLC fingerprint analysis of traditional diabetes jamu diabetes plant materials. JTEK 68(1): 83-88.

Sriyapai C, Upakorn, Sangwatanaroj, Kongkathip, Kritiyanunt. 2009. Hypoglicemic effect of Tinospora crispa dry powder in out patient with metabolic syndrome at king chulalongkorn memorial hospital. $J$ Health Res 23(3): 125-133.

Stoenoiu CE, Bolboaca AD, Jantschi L. 2006. Mobile phase optimization for steroid separation. Med Informatics 18:17-24.

Vivi L, Wiryawidagdo S, Kardono SBL. 2006. Brine shrimp lethality test (BSLT) dari berbagai fraksi ekstrak daging buah dan kulit biji mahkota dewa (Phaleria macrocarpa). Bul. Penel.Kesehatan 34(3): 111-118.

Wahyuni S. 2010. Pengoptimuman dan validasi sidik jari kromatografi cair kinerja tinggi ekstrak Phillanthus niruri [Tesis]. Bogor(ID): Institut Pertanian Bogor.

Wang dan Fang. 2010. The Optimization of medicine formulation using mixture experiments [Prosiding]. Hongkong: IMECS Vol III.

Wijaya SH, Husnawati, Afendi FM, Darusman LK, Batubara I, Md. Altaf-Ul-Amin, Sato T, Ono N, Sugiura T, Kanaya S.2014. Supervised Clustering Based on DPClusO: Prediction of Plant-Disease Relations Using Jamu Formulas of KNApSAcK Database. BioMed Hindawi.2014: 1-15.

Yonanda RJ. 2011. Formulasi ekstrak sambiloto (Andrographis paniculata) dan Brotowali (Tinospora crispa) sebagai inhibitor $\alpha$-glukosidase dan analisis sidik jari menggunakan teknik kromatografi [Skripsi].Bogor (ID): Institut Pertanian Bogor. 